\title{
PREVALENCE AND IMPACT OF HEADACHE AND MIGRAINE AMONG BRAZILIAN TUPINIQUIM NATIVES
}

\author{
Renan Barros Domingues ${ }^{1,2}$, Priscila Bacchetti Cezar', Jair Schmidt Filho', \\ Milton Nunes de Moraes Filho', Mariana Novaes Pinheiro', João G. Marchiori', \\ Francine Brito', Simone Aires Domingues ${ }^{7}$
}

\begin{abstract}
This is the first study to evaluate the prevalence of headache and migraine among Tupiniquim Brazilian natives. A high prevalence of headache was found and the most prevalent headache was migraine. Women were more commonly affected than men. A high impact of headache was found, especially among migraineurs. Half of the headache sufferers were under medical assistance for headache given by the government Family Health Program (PSF). Most of them declared to use common analgesics. None of them was taking prophylactic therapy for this medical problem.
\end{abstract}

KEY WORDS: Brazilian Tupiniquim natives, headache, impact, migraine, prevalence.

\section{Prevalência e impacto da cefaléia e da migrânea em uma população de índios Tupiniquins}

Resumo - Este é o primeiro estudo a avaliar prevalência de cefaléias entre índios tuiniquins do Brasil. A prevalência de cefaléia encontrada nesta população foi alta, sendo que a migrânea foi a mais frequente. Encontrou-se maior prevalência de cefaléias entre as mulheres do que entre os homens. $O$ impacto da cefaléia foi considerável, sendo maior entre os portadores de migrânea do que nas cefaléias não migranosas. Cinquenta por cento dos indivíduos com cefaléia recebiam atendimento médico devido a este problema, através do Programa de Saúde da Família (PSF). O tratamento empregado consistia apenas em analgésicos comuns para alívio das crises. Nenhum indivíduo estava em uso de tratamento profilático.

PALAVRAS-CHAVE: cefaléia, indios Tupiniquins brasileiros, impacto, migrânea, prevalência.

Primary headaches are highly frequent and are associated with considerable impact on quality of life'. Several studies have focused on the epidemiology of headache in different cities and in specific populations in Brazil ${ }^{2-7}$. However there are not previous reports about the prevalence and impact of headaches among Brazilian natives. Here we report the results of the first epidemiological headache survey among tupiniquim brazilian Indians living in a reservation community in Aracruz, ES, Brazil. Aracruz is located 83 kilometers from Vitória, the Espírito Santo capital. Its total population is nearly 73000 inhabitants. Today Aracruz has roughly 1500 natives divided into six reservations. Those Indians are of two tribes: tupiniquim and guarani.

This study aimed to identify the prevalence and the impact of headache and migraine, and the modalities of headache treatments used in one of these tupiniquim communities.

\section{METHOD}

A questionnaire was administered by a group of intern medical students attending the Headache Clinic of the School of Health Sciences of Santa Casa de Misericórdia de Vitória. These medical students were attending the Headache Clinic as trainees, for at least a year, and had experience with the International Headache Society diagnostic criteria ${ }^{8}$. This questionnaire was applied to inhabitants of a small community of nearly 180 families of tupiniquim Indians. The Indian volunteers were reached by a door to door search by the students in a weekend day. Selected individuals were all adult Indians who were at home at the time of the search and were able to understand the questions and answer about their symptoms. All the visits were accompanied by at least one agent of the Family Health Program (PSF) of that community.

Gender, age, and main occupation data were recorded. All volunteers were asked about the presence of headache in the

${ }^{1}$ Headache Clinic, Department of Pathology, School of Health Sciences of Santa Casa de Misericórdia de Vitória, Vitória ES, Brazil; ${ }^{2}$ Neurosciences Postgraduation Program, Federal University of Minas Gerais (UFMG), Belo Horizonte MG, Brazil.

Received 10 October 2008, received in final form 14 January 2009. Accepted 8 April 2009.

Dr. Renan Barros Domingues - Avenida Nossa Senhora da Penha 699 / 709 - 29055-137 Vitória ES - Brasil.E-mail: renan-domingues@uol.com.br 
last six months. A headache questionnaire was applied. This questionnaire has investigated about type of pain (throbbing or pressing), localization and duration of pain, headache frequency, and associated features, such as nausea, vomiting, photophobia, and phonophobia. The impact of headache on their activities was registered asking how frequently the subject has missed work, household work, or study in the last six months due to headache. The answers were classified in none, less than once a month, and more than once a month. Migraine was diagnosed according to the International Headache Society criteria ${ }^{8}$. The individuals with headache but not fulfilling migraine diagnosis criteria were classified as having non migraine headache. Statistical comparisons between migraine and non migraine subjects were performed by Fisher's Exact Two Tailed Test. The level of significance was set at $\mathrm{p}<0.05$. This study protocol was approved by the local authorities and by the health staff of that community. Written consent was obtained from each participant.

\section{RESULTS}

The questionnaire was applied to 102 Indians; sixty nine of them were (67.6\%) women. Ages ranged from 18 to 81 years, the mean age was $30.5 \pm 16.9$. The number of individuals referring headache in the last six months was 62 $(60.7 \%)$. The six months headache prevalence was $65.2 \%$ among women and $51.5 \%$ among men. Migraine was diagnosed in $64 \%$ of the subjects reporting headache. Thirty three women ( $47.8 \%$ of all women) and seven men $(21.2 \%$ of all men) had migraine.

Among those with non migraine headache $72.7 \%$ referred that headache had not impact on their activities, $22.7 \%$ declared that headache had impact less than once a month, and $4.5 \%$ reported that headache had impact more than once a month. Impact of the headache among migraneurs was reported to occur more than once a month by $37.5 \%$ and less than once a month by $35.5 \%$. Only $25 \%$ of the migraneurs declared no impact of migraine on their activities. The proportion of subjects reporting impact of headache on their activities was significantly higher among individuals with migraine than among individuals with non migraine headache $(p<0.05)$.

Most $(89.2 \%)$ of the headache sufferers declared to use analgesics for pain relief, half of the individuals referring headache were under medical attention for this problem, all of them were under assistance of PSF program. The remaining individuals were taking analgesics without medical prescription. The most used analgesic drug was dypirone (85.2\%), followed by acetaminophen (35.2\%), acetilsalicilic acid (9.2\%), the combination of dypirone, orphenadrin, and caffein (9.2\%), and ergotics (1.8\%). None of them were under prophylactic therapy.

\section{DISCUSSION}

Some studies have evaluated headache among native.
In a study of prevalence of headache among US adolescents, Rhee has reported that a higher rate of recurrent headaches among American Indians (35.6\%) had a higher rate of recurrent headaches than white adolescents $(32.1 \%)^{9}$. A high frequency of migraine among Ecuadorian Amazon Indians was also found ${ }^{10}$. In Brazil, Carod-Artal and Vázquez-Cabrera registered the occurrence of migraine among natives of a Kamayura tribe in Alto Xingu, Mato Grosso, however, there were not prevalence data in this study". As far as we know our study is the first epidemiological survey of headache and migraine using IHS diagnostic criteria among tupiniquim Indians in Brazil.

We have found that headache was a frequent medical problem in this Brazilian Tupiniquim community. It is not possible to compare our data with previous Brazilian studies of headache prevalence because of methodological differences, however, our data suggest a significant headache prevalence among Indians as it has been previously verified in urban populations ${ }^{12}$. As in previous studies ${ }^{13,14}$, migraine was more prevalent among women. Migraine was identified in $47.8 \%$ of all women and in $21.2 \%$ of all men. Previous studies have shown that migraine is highly disabling ${ }^{15}$. In our study migraine had a significant impact on work activities. Seventy five percent of the subjects with migraine declared that migraine had impact on their activities. Considering the high genetic, social, and economic heterogeneity in the Brazilian population it is important that future studies continue to analyze the migraine prevalence and impact in different Brazilian regions and different Brazilian ethnic groups ${ }^{16,17}$. Future studies should also evaluate lifestyle influences on the migraine prevalence and impact in different populations ${ }^{18}$.

Most of the headache sufferers declared to use analgesic drugs. Half of them were using these drugs according to medical prescription. This figure contrasts with the reality seen in an urban area in Brazil. In a previous study we have showed that only $9.2 \%$ of the headache sufferers were under medical treatment for headache in a large ${ }^{12}$. It seems that the PSF program has allowed many of the Indians to treat their headache problem with a physician, however, none of the headache sufferers were under prophylactic therapy. Considering that $75 \%$ of the Indians with migraine declared impact on their activities and that $37.5 \%$ had impact more than once a month it is reasonable to consider that some of these individuals would improve with migraine prophylactic therapy. It is possible that they were not under prophylactic treatment because the lack of a specific training of PSF physicians in headache and migraine treatment. This type of training would possibly reduce the impact of migraine and other types of headache in this and in other non urban brazilian populations.

In conclusion, we have found a significant prevalence 
and impact of headache, especially migraine, among Brazilian Tupiniquim natives. Headache treatment training for physicians working in such communities should possibly contribute to reduce the impact of these diseases. Future studies are still needed to improve our knowledge about headache and migraine in indian populations, particularly among native Indians not yet influenced by the industrialized society.

\section{REFERENCES}

1. Barea LM, Forcelini CM. A epidemiologia das cefaléias primárias. In Speciali JG, Silva WF (Eds). Cefaléias. São Paulo: Lemos Editorial, 2002:51-61.

2. Bigal ME, Bigal JO, Bordini CA, Speciali JG. Prevalence and costs of headaches for the public health system in a town in the interior of the state of São Paulo. Arq Neuropsiquiatr 2001;50: 504-511.

3. Costa MZ, Soares CB, Heinisch LM, Heinisch RH. Frequency of headache in the medical students of Santa Catarina's Federal University. Headache 2000;40:740-744.

4. Sanvito WL, Monzillo PH, Peres MF, et al. The epidemiology of migraine in medical students. Headache 1996;36:316-319.

5. Bigal ME, Bordini CA, Speciali JG. Etiology and distribution of headaches in two Brazilian primary care units. Headache 2000;40:241-247.

6. Queiroz LP, Peres MFP, Kowacs F, et al. Chronic daily headache in Brazil: a nationwide population based study. Cephalalgia 2008;28:1264-1269.

7. Queiroz LP, Peres MFP, Piovesan EJ, et al. A nationwide population-based study of tension type headache in Brazil. Headache 2008; doi: 10.1111/j.1526-4610.2008.01227.x
8. Headache Classification Subcomitte of the International Headache Society. The Internacional Classification of Headache Disorders. $2^{\text {nd }}$ Edition. Cephalalgia 2004;24:1-160.

9. Rhee H. Prevalence and predictors of headache in US adolescents. Headache 2000;40:528-538.

10. Russo EB. Headache treatments by native people of the Ecuadorian Amazon: a preliminary cross-disciplinary assessment. J Ethnopharmacol 1992;36:193-206.

11. Carod-Artal FJ, Vásquez-Cabrera C. Antropologia neurológica entre los indios Kamayurá del Alto Xingú. Rev Neurol 2001;32:688-695.

12. Domingues RB, Kuster GW, Dutra LA, Santos JG. Headache epidemiology in Vitoria, ES. Arq Neuropsiquiatr 2004;62: 588-591.

13. Morillo LE, Alarcon F, Aranaga N, et al. Clinical characteristics and patterns of medication use of migraneurs in Latin America from 12 cities in 6 countries. Headache 2005;45:103-104.

14. Rasmussen BK. Epidemiology of headache. Cephalalgia 2001;21:774-777.

15. Bigal ME, Fernandes LC, Moraes FA, Bordini CA, Speciali JG. Migraine prevalence and impact in emplyees of the clinical hospital of the medical school of Ribeirão Preto-USP. Arq Neuropsiquiatr 2000;58:431-436.

16. Mitsikostas DD, Tsaklakidou D, Athanasiadis N, Thomas A. The prevalence of headache in Greece: Correlations to latitude and climatological factors. Headache 1996;36:168-173.

17. Dahlof C, Linde M. One year prevalence of migraine in Sweden: a population-based study in adults. Cephalalgia 2001;21: 664-671.

18. Blau JN. The effect of national lifestyles. Cephalalgia 1998;18 (Suppl 21):S23-S25. 